\title{
ANY-WHERE ANY-TIME: AMBIGUITY AND THE PERCEIVED PROBABILITY OF APPREHENSION
}

\author{
Elena Kantorowicz-Reznichenko*
}

\begin{abstract}
Enforcement is a costly endeavor. Thus, governments ought to be innovative in designing less costly policies, yet, effective in preventing crime. To this end, this paper suggests using insights from behavioral law and economics. Empirical evidence demonstrates that police have an important effect in deterring crime. However, increasing the number of policemen is a costly policy. Therefore, this paper explores policy changes, which exploit offender's ambiguity aversion in order to reduce crime without increasing the police force. Namely, empirical evidence suggests that criminals are better deterred by ambiguous detection. Thus, this paper analyzes the ways to randomize the apprehension strategies to meet this end. Furthermore, it provides new evidence, based on a survey carried out for the purpose of this paper, that potential violators are largely not aware of policy changes. Inasmuch as the information regarding the intensified uncertainty is essential to its success, this paper discusses the possibility to increase criminals' awareness through the "availability heuristic."
\end{abstract}

\section{INTRODUCTION}

Criminal justice expenditure constitutes a significant part of countries' spending. For instance, in 2007, the United States (U.S.) spent \$288 billion on police, correction institutions, and courts. ${ }^{1}$ Governments often seek ways to reduce this expenditure without harming the efficiency of combating crime. The need for a reduction in this expenditure grew even further in light of the global crisis over the period 2008 - 2010 and following sovereign debt crisis in 2010 2012 in the European Union (EU). ${ }^{2}$ Resulting budget consolidations in some of

\footnotetext{
* Rotterdam Institute for Law and Economics (RILE), Erasmus School of Law, Erasmus University Rotterdam. E-Mail: reznichenko@law.eur.nl. The author would like to thank Jonathan Klick, Jeffrey Rachlinski, Christoph Engel, Louis Visscher, Alessio Pacces, Michael Faure, Paul Mevis, Giuseppe Melis and Qi (George) Zhou as well as participants of the European Association of Law and Economics (EALE) conference, and of workshops and faculty seminars at Erasmus University Rotterdam and University of Hamburg for their helpful comments. In addition, the author wishes to thank, Katherine Hunt and Anna Barbanti for their assistance with the survey. She gratefully acknowledges the financing support by Vereniging Trustfonds Erasmus Universiteit Rotterdam. She would also like to express her appreciation to the editors of the UMKC Law Review for their assistance and remarks. Special thanks go to Jaroslaw Kantorowicz for all the helpful suggestions and support. All possible mistakes remain, however, her own.

${ }^{1}$ See Tracey Kyckelhahn, Justice Expenditures and Employment, FY 1982-2007 Statistical Tables, U.S. DeP'T OF Justice, Bureau of Justice Statistics, Wash. D.C. (Dec. 2011), www.bjs.gov/content/pub/pdf/jee8207st.pdf.

${ }^{2}$ See generally Ministry of Security and Justice to Cut Spending by over $€ 1$ Billion, Gov'T OF THE NETH. (May 17, 2013), http://www.government.nl/news/2013/05/21/ministry-of-security-andjustice-must-cut-spending-by-over-1-billion.html (noting the Dutch reforms to reduce expenditure of the Security and Justice Ministry due to the austerity plans). Similar austerity targets may be
} 
the EU countries led to significant cuts in expenditure on enforcement, i.e. police and prison expenditure. ${ }^{3}$ For instance, in the United Kingdom (UK) the budget of public order and safety, in relative terms, was reduced significantly by the austerity measures in recent years. ${ }^{4}$ Similarly, the police authorities in Finland face budget reductions in the upcoming period. ${ }^{5}$ Despite the necessity of budget cuts, their implementation in the enforcement of law ought to be cautious. To be precise, governments might be myopic regarding the elements of the enforcement system, which might continue functioning with reduced budgets. Therefore, empirical findings concerning the importance of different crime control measures should be taken into account when deciding on austerity plans.

The law and economics approach to enforcement asserts that crime control can be achieved through deterrence. ${ }^{6}$ Empirical evidence largely supports the concept of deterrence and discusses the effectiveness of severity and certainty of punishment. ${ }^{7}$ According to those studies, the deterrence effect mostly attributed to the probability ${ }^{8}$ of punishment, rather than to its severity. ${ }^{9}$ Furthermore, a number of studies demonstrated a significant deterrence effect due to police force presence. ${ }^{10}$

Taking into consideration the significant costs of police services, ${ }^{11}$ policy implications of the abovementioned evidence are a challenging task. Implementing constant police surveillance would be a burden on the country's budget, especially in light of the recent EU debt crisis. Furthermore, this kind of

found in other European countries. In England and Wales the prison service budget cuts led to a proposal to halve the penalty for criminals who plead guilty in the earliest stage. See Dominic Casciani, National Audit Office Warns over Prisons Savings, BBC News (Sep. 18, 2012), http://www.bbc.co.uk/news/uk-politics-19630614. In Finland, the austerity needs led to planed budges cuts in police expenditure. Interview with Esa Käyhkö, Ministerial Adviser, Ministry of the Interior, Police Department, Helsinki, Finland. (June 7, 2012).

${ }^{3}$ See Casciani, supra note 2.

4 General Government Expenditure by Function (COFOG), Eurostat (Mar. 13, 2015) http://appsso.eurostat.ec.europa.eu/nui/show.do?dataset=gov_a_exp\&lang=en.

${ }^{5}$ Interview with Esa Käyhkö, supra note 2.

${ }^{6}$ See generally Gary S. Becker, Crime and Punishment: An Economic Approach, 76 J. POLIT. ECON. 169, 170 (1968).

7 See Dieter Dölling, et al., Meta-Analysis of Empirical Studies on Deterrence in Punitivity InTERnAtional Developments 362 (Helmut Kury \& Evelyn Shea eds., 2011).

8 "Probability" and "certainty" are used interchangeably in this paper.

${ }^{9}$ See DöLling ET AL., supra note 7, at 362.

${ }^{10}$ See generally Jonathan Klick \& Alexander Tabarrok, Using Terror Alert Levels to Estimate the Effect of Police on Crime, 48 J.L. \& EcON. 267 (2005) [hereinafter Terror Alert Levels]; Jonathan Klick \& Alexander Tabarrok, Police, Prisons, and Punishment: the Empirical Evidence on Crime Deterrence, HANDBOOK ON THE Economics of CRIME 127-143 (Bruce L. Benson \& Paul R. Zimmerman eds., 2012); Rafael Di Tella \& Ernesto Schargrodsky, Do Police Reduce Crime? Estimates Using the Allocation of Police Forces After a Terrorist Attack, 94 AM. ECON. REV. 115 (2004); Mirko Draca, Stephen Machin, \& Robert Witt, Panic on the Streets of London: Police, Crime and the July 2005 Terror Attacks, 101 Am. ECON. REV. 2157 (2011).

${ }^{11}$ See generally Terror Alert Levels, supra note 10, at 267 (stating that the US expenditure on police is over $\$ 65$ billion per year, an amount that is more than one third of the expenditure on education). 
policy possibly will have high social costs. Namely, the law-abiding citizens might sense discomfort from having constant police presence. On the other hand, increasing police force only to a limited extent might lead to a displacement effect. In light of the current circumstances there is therefore a need to design an enforcement mechanism, which remains effective without a significant increase in the enforcement costs.

This paper adopts the behavioral approach to law and economics (behavioral approach) in order to design a cost-effective apprehension system. The behavioral approach mainly discusses the cognitive biases, which people in general, and agents in the legal system in particular, are subject to in order to explain behavior. ${ }^{12}$ This paper takes one step forward and explores the ways to "utilize" those biases in order to improve criminal justice policy. Although some scholars offer policy changes based on cognitive biases in other areas, ${ }^{13}$ this approach is rarely pursued in the criminal justice policy context. ${ }^{14}$

Based on insights from the behavioral law and economics, this paper discusses detailed policy changes, which enhance the deterrence effect without significantly increasing the given resources. In addition, it includes in-depth analysis of possible challenges of this policy and offers solutions. The suggested policy consists of two steps.

The first step is to introduce ambiguity into the probability of detection. This proposition is based on empirical evidence suggesting that people are averse to ambiguity, thus, in some circumstances they are deterred better by random probability of detection. ${ }^{15}$ One way to achieve this is, for example, by introducing random patrol projects. To be precise, the police department ought to send police force patrols to problematic and "normal" areas on random dates. Inasmuch as those patrols are random, criminals would not be able to calculate the probability of detection. Namely, if without these random patrols the criminal has the possibility to know his risk of being detected, the new enforcement system would make it impossible to anticipate the chances of being caught. For instance, prior to this policy the criminal believes he has $20 \%$ chance

12 See generally Cass R. Sunstein, The Future of Law and Economics: Looking Forward: Behavioral Analysis of Law, 64 U. CHI. L. REV. 1175 (1997); Richard H. McAdams \& Thomas S. Ulen, Behavioral Criminal Law and Economics (Univ. of Chicago Law School, John M. Olin Law and Economics, Working Paper No. 440 (2d Series), 2008).

13 See Richard H. Thaler \& Cass R. Sunstein, Nudge: Improving Decisions about Health, WEALTH, AND HAPPINESS 19-22 (2008).

${ }^{14}$ See Christine Jolls, Cass R. Sunstein, \& Richard Thaler, A Behavioral Approach to Law and Economics, 50 STAN. L. REV. 1471, 1540 (1998).

${ }^{15}$ See generally Tom Baker, Alon Harel \& Tamar Kugler, The Virtues of Uncertainty in Law: An Experimental Approach, 89 IowA L. REv. 443, 447 (2004); Alon Harel \& Uzi Segal, Criminal Law and Behavioral Law and Economics: Observations on the Neglected Role of Uncertainty in Deterring Crime, 1 Am. Law. Econ. Rev. 276, 293 (1999); Thomas A. Loughran, et. al, On Ambiguity in Perceptions of Risk: Implications for Criminal Decision Making and Deterrence, 49 CRIminology 1029, 1029 (2011); Lawrence W. Sherman, Police Crackdowns: Initials and Residual Deterrence, 12 CRIME \& JUST. 1, 12 (1990). 
of being caught committing theft, whether based on clearance rates of previous years, or his and his acquaintances' experience. Following the introduction of the new random patrols, he will not be able to make any estimation.

The second step of the policy is to make those random patrol projects salient and highly publicized. This paper provides new evidence, based on a recently pursued survey in the area of tax policies in Italy, that potential violators have bounded rationality and limited knowledge of policy changes. Forasmuch as the awareness of the criminal to the new random detection is crucial to its success, this paper suggests using the "availability heuristics" to increase this awareness. According to the latter, saliency of an event, increases its perceived frequency. ${ }^{16}$ Thus, covering the random detection methods in the media, and publicizing them through other channels, would increase criminals' awareness of the vague probability of apprehension. This policy, in turn, might enhance the deterrent effect by making potential offenders to be aware they are acting in an entirely uncertain environment.

The existing literature on ambiguity aversion, although briefly mentioning possible policy implications, does not investigate in depth the structured policy changes that would use ambiguity. In addition, those studies do not discuss the bounded rationality of offenders, which makes them less informed. Lack of awareness to the new policy of ambiguity might significantly impede its effectiveness in deterring crime, thus, this problem should be addressed. This paper attempts to fill these gaps.

This paper is structured as follows. Section I discusses the rational and the behavioral approaches to crime and presents empirical evidence for the importance of certainty of detection and punishment. Section II presents the suggested changes to the detection policy. Possible limitations are addressed in Section III. Finally, some concluding remarks are offered.

\section{RATIONAL AND BEHAVIORAL APPROACHES TO CRIME}

\section{A. The Deterrence Theory and Empirical Evidence to Support it}

The description of criminal behavior based on the rational choice theory was first offered by Gary Becker. ${ }^{17}$ The author suggested that criminals, as other enforcement actors, are rational and respond to incentives. ${ }^{18}$ Thus, by raising either the severity of the expected punishment or the probability of being punished, the enforcement authorities are able to alter the expected costs of

\footnotetext{
${ }^{16}$ See Amos Tversky \& Daniel Kahneman, Availability: A Heuristic for Judging Frequency and Probability, 5 COGNITIVE PSYCHOL. 207, 219-20 (1973).

${ }^{17}$ Becker, supra note 6, at 170.

${ }^{18} \mathrm{Id}$. at 177.
} 
crime. ${ }^{19}$ In turn, this is expected to deter potential offenders from committing crimes. ${ }^{20}$

A great deal of empirical studies have tested the abovementioned theory and shown that the deterrence effect largely exists. ${ }^{21}$ Although some scholars found supporting evidence for the effect of severity of punishment, ${ }^{22}$ most of the empirical literature on this issue suggests that the certainty of apprehension and punishment has the dominant effect on deterrence. ${ }^{23}$

For instance, Michael Block and Vernon Gerety present an experimental study where they show, in accordance with the existing literature, that prisoners are more strongly deterred by increased probability of detection, while students respond more to the severity of punishment. ${ }^{24}$ A more recent study, by Horst Entorf, shows the importance of certainty of apprehension and punishment for the deterrence of criminals, exploiting the differences in the level of enforcement between the German Länder. ${ }^{25}$ The author presents evidence that the growing practice of dismissing cases by prosecutors results in weaker deterrence of crimes. ${ }^{26}$ The reason for that is this practice can be counted as lowering the certainty of punishment. ${ }^{27}$ Another important factor in deterring crime shown in the paper is a higher clearance rate. ${ }^{28}$ On the other hand, based on his findings,

${ }^{19} I d$. at 170 .

${ }^{20} \mathrm{Id}$.

${ }^{21}$ See Daniel Kessler \& Steven D. Levitt, Using Sentence Enhancements to Distinguish Between Deterrence and Incapacitation, 42 J.L. \& ECON. 343, 344 (1999); Francesco Drago, Roberto Galbiati \& Pietro Vertova, The Deterrent Effects of Prison: Evidence from a Natural Experiment, 117 J. Pol. Econ. 257, 258 (2009); Steven D. Levitt \& Thomas J. Miles, Empirical Study of Criminal Punishment, 1 Handbook of LAW And Economics 455-495 (Mitchel A. Polinsky and Steven Shavell eds., 2007); Steven D. Levitt, Why Do Increased Arrest Rates Appear to Reduce Crime: Deterrence, Incapacitation, or Measurement Error?, 36 ECON. INQUIRY 353 (1998); Steven D. Levitt, Juvenile Crime and Punishment, 106 J. PoL. ECon. 6 (1998). But see David S. Lee \& Justin McCrary, Crime, Punishment, and Myopia, (Nat'l Bureau of Econ. Research, Working Paper No. 11491, 2005).

22 See Eric Helland \& Alexander Tabarrok, Does Three Strikes Deter? A Nonparametric Estimation, 42 J. of HuM. Resources 309, 309 (2007); David McDowall, Colin Loftin \& Brian Wiersema, Comparative Study of the Preventive Effects of Mandatory Sentencing Laws for Gun Crimes, 83 J. CRIM. L. \& CRIMINOlogy 378, 378 (1992); Silvia M. Mendes, Certainty, Severity, and Their Relative Deterrent Effects: Questioning the Implications of the Role of Risk in Criminal Deterrence Policy, 32 The Pol'y Stud. J. 59, 59 (2004).

${ }^{23}$ See DöLling, ET. AL, supra note 7, at 362.

24 See generally Michael K. Block \& Vernon E. Gerety, Some Experimental Evidence on Differences between Student and Prisoner Reactions to Monetary Penalties and Risk, 24 J. LEGAL STUD. 123, 123 (1995).

${ }_{25}$ See generally Horst Entorf \& Hannes Spengler, Crime, Prosecutors, and the Certainty of Conviction, 39 EUROPEAN J.L. \& ECON. 167 (2015).

${ }^{26} \mathrm{Id}$. at 175 .

${ }^{27}$ See id. at 189.

${ }^{28}$ Id. "Clearance rate" is the proportion of cases that have been solved by the police (i.e. the suspect was identified and caught) out of the total number of reported crimes. 
the author concludes that the severity of punishment does not constitute a significant deterrent factor. ${ }^{29}$

Moreover, a number of studies were able to isolate the effect of increased police protection on the number of committed crimes. ${ }^{30}$ Those studies show an important deterrent effect that is achieved by increasing the police presence and the probability of detection. ${ }^{31}$ Some of these studies exploit the changes in police presence, which resulted from terrorist attacks. ${ }^{32}$ Using empirical methods, the studies demonstrate a significant negative effect of police presence on crime. ${ }^{33}$ Although the effect is investigated in different countries, the authors reach similar conclusions. An additional study, by John MacDonald, Jonathan Klick, and Ben Grunwald, provides evidence for the long-term effect of an increased police protection on crime, across most crime categories. ${ }^{34}$ This is an important step in analyzing the crime control system since previous studies have not been able to demonstrate this effect and some even presented a positive correlation between crime rates and size of the police force..$^{35}$

The growing empirical literature supporting the effectiveness of police in deterring crime strengthens the rationale to use this kind of crime control policy. However, there are two main limitations of such policy. First, increasing the presence of police in a significant manner imposes considerably high tangible costs on enforcement authorities. All the more so, in the face of findings that suggest police presence has a merely local deterrent effect. ${ }^{36}$ The latter evidence implies that in order to achieve deterrence, policemen should essentially be placed everywhere. The second limitation is that constant police presence might have high social costs. Notwithstanding the fact people aspire to feel safe, they may not wish to be regularly under surveillance. Increasing the police force on the streets might impede people's sense of individual freedom and involuntarily restrict their self-expressive behavior. Those non-monetary costs bear the risk of diminishing the legitimacy of such law enforcement policy.

${ }^{29} I d$.

${ }^{30}$ See Terror Alert Levels, supra note 10, at 267; Di Tella \& Schargrodsky, supra note 10, at 115; Draca, Machin, \& Witt, supra note 10, at 2157.

${ }^{31} \mathrm{Id}$.

32 See Draca, Machin, \& Witt, supra note 10, at 2157.

${ }^{33}$ See Terror Alert Levels, supra note 10, at 267; Di Tella \& Schargrodsky, supra note 10, at 115; Draca, Machin, \& Witt, supra note 10, at 2157.

${ }^{34}$ See John M. MacDonald, Jonathan Klick, and Ben Grunwald, The Effect of Privately Provided Police Services on Crime, 4 (Penn Law: Legal Scholarship Repository, Working Paper No. 430, 2012).

${ }^{35}$ See Samuel Cameron, The Economics of Crime Deterrence: A Survey of Theory and Evidence, 41 Kyklos 301, 315 (1988).

${ }^{36}$ See Di Tella \& Schargrodsky, supra note 10, at 130. In other words, the police force is not only costly, but also has a limited local effect, meaning that crimes might be transferred to other places, where there is no police presence, and impose additional costs of crime. 


\section{B. Behavioral Approach to Crime}

In recent decades the model of the rational choice theory is being criticized by the behavioral approach. Based on empirical evidence from the social sciences, ${ }^{37}$ scholars assert that people do not always act rationally in its standard meaning. For instance, they point out other factors motivating decision makers aside from self-maximization goals. ${ }^{38}$ Forasmuch as human behavior deviates from the rational choice model, not taking those factors into account turns the classical model into a normative statement rather than a positive description. Thus, the predictable power of this model is called into question. ${ }^{39}$

An important area for the law and economics analysis where social scientists find deviations from the rational choice theory is the decision making under uncertainty process. A great deal of empirical evidence has demonstrated that while calculating probabilities, persons systematically use rules-of-thumbs based on life experience. ${ }^{40}$ People have bounded rationality rather than acting as perfectly rational individuals with complete information. ${ }^{41}$

Nevertheless, the behavioral approach does not argue that people are unpredictable agents who make random mistakes. On the contrary, behavioral proponents believe the decision makers are subject to systematic biases, which makes it possible to predict and even to model their behavior. ${ }^{42}$ As described by Dan Ariely, "these irrational behaviors of ours are neither random nor senseless. They are systematic, and since we repeat them again and again, predictable." ${ }^{43}$ Consequently, the purpose of the behavioral approach is not to undermine the economic framework, but to strengthen its predictive and analytical power. ${ }^{44}$

The behavioral approach to law and economics was applied to criminal law as well. In this context, neither the criminals nor other criminal justice players are believed to act fully rationally. ${ }^{45}$ Nonetheless, similarly to rational choice proponents, behavioral scholars believe that potential criminals respond to incentives and take into account, at least roughly, the costs and benefits of their crimes. ${ }^{46}$ The assumption, however, is that the estimations on which they base

\footnotetext{
${ }^{37}$ See generally John Conlisk, Why Bounded Rationality?, 34 J. ECON. LiT. 669, 669 (1996).

${ }^{38}$ See id. at 673; Jolls, Sunstein, \& Thaler, supra note 14, at 1473.

${ }^{39}$ See Sunstein, supra note 12, at 1175; Jolls, Sustein, \& Thaler, supra note 14, at 1473-74.

40 See Amos TVERSKy \& Daniel Kahneman, Judgment under Uncertainty: Heuristics and Biases 3-20 (Daniel Kahneman, Paul Slovic \& Amos Tversky eds., 1982).

${ }^{41}$ See Herbert A. Simon, A Behavioral Model of Rational Choice, 69 Q. J. Econ. 99, 101 (1955).

42 See Daniel Kahneman \& Amos Tversky, Prospect Theory: An Analysis of Decision under Risk, 47 Econometrica 263, 284 (1979).

${ }^{43}$ Dan Ariely, Predictably IrRational xx (2009).

${ }^{44}$ See Jolls, Sunstein, \& Thaler, supra note 14, at 1476.

${ }^{45}$ See generally McAdams \& Ulen, supra note 12, at 2.

${ }^{46}$ See Jolls, Sunstein, \& Thaler, supra note 14, at 1538.
} 
their decisions are subject to heuristics and biases. ${ }^{47}$ Thus, the following sections examine the ways in which policy makers may use those biases in order to design an efficient and less costly detection policy.

\section{Ambiguity Aversion}

The distinction between risk and uncertainty (the latter named in this paper as "ambiguity") can be traced back to Frank Knight. ${ }^{48}$ Whereas in the former the probabilities of the occurrence of an event are known, and the uncertainty only applies to the outcome, in the latter, the precise likelihoods are not given. For instance, a toss of a coin is a risky event since there is a probability of $50 \%$ chance of heads or tails. On the contrary, deciding on which player to place a bet on in a tennis game is an ambiguous decision if the decisionmaker has no prior knowledge about the previous performance of both players. The reason for this is that it is difficult to assign any probability that player A or B would win without knowing his and his opponent's prior game records.

Ambiguity aversion is an empirically well-established phenomenon. The best-known experiment is that of Daniel Ellsberg (Ellsberg Paradox). ${ }^{49}$ The experiment is designed in the following way. People are presented with two urns, A and B, which contain black and red balls. Following this, they are asked about their preferences regarding the urn and the ball. They are offered $\$ 100$ if the drawn ball is the one they bet on. The subjects are told that urn A contains 100 balls, yet the proportions of red and black balls are not known and can range from zero red balls and 100 black balls, and vice versa. In urn B there are 50 black balls and 50 red balls. The majority of people prefer to bet on balls from urn B, regardless whether they bet on a red or a black ball..$^{50}$ If the subjects' choice reflects their perception of probabilities, for them the probability of a red ball from urn $\mathrm{B}$ is higher than the probability of a red ball from urn A. At the same time however, the results suggest that the probability of drawing a black ball from urn $\mathrm{B}$ is also higher than the probability of drawing a black ball from

\footnotetext{
${ }^{47}$ See generally McAdams \& Ulen, supra note 12, at 4-5. See Christine Jolls, On Law Enforcement with Boundary Rational Actors, in THE LAW AND ECONOMICS OF IRRATIONAL BeHAVIOUR (Francesco Parisi and Vernon L. Smith eds., 2005), 268-286; Frans van Winder \& Elliott Ash, On the Behavioral Economics of Crime, CENTER FOR RESEARCH IN EXPERIMENTAL ECONOMICS AND Political Decision-making 10 (2009), http://dare.uva.nl/document/181782. A close stream of literature to the behavioral approach is criminology. They as well deviate from the rational model of behavior. However, similarly to behavioral scholars, they believe criminals react to incentives. See Daniel S. Nagin, Criminal Deterrence Research at the Outset of the Twenty-First Century, 23 CRIME AND JUSTICE 1, 6-8 (1998) (showing that if criminals perceive the risk of sanction as high, they tend to commit less crimes. In other words, although this discipline relies on the perceptual deterrence rather than the actual, it still shows a deterrence effect).

${ }^{48}$ Frank KNight, Risk, UnCERTAinty AND Profit (1921).

${ }^{49}$ Daniel Ellsberg, Risk, Ambiguity, and the Savage Axioms, 75 Q. J. Econ. 643 (1961).

${ }^{50} \mathrm{Id}$. at $650-51$.
} 
urn A. ${ }^{51}$ This choice is confusing since it implies that $\mathrm{P}\left(\mathrm{B}_{\mathrm{B}}\right)+\mathrm{P}\left(\mathrm{R}_{\mathrm{B}}\right)>1$, where $\mathrm{P}\left(\mathrm{B}_{\mathrm{B}}\right)$ is the probability to draw a black ball from urn $\mathrm{B}$, and $\mathrm{P}\left(\mathrm{R}_{\mathrm{B}}\right)$ is the probability to draw a red ball from urn B..$^{52}$ Those results suggest that people are averse to ambiguous choices. ${ }^{53}$

Following Ellsberg's finding, many scholars conducted experiments seeking to replicate his results. Those attempts demonstrate ambiguity aversion in different contexts and thus, increase its validity. ${ }^{54}$ The effect of ambiguity aversion is shown in the context of losses as well as gains. ${ }^{55}$ Moreover, some studies present evidence that people not only refrain from choosing an ambiguous choice, but they are even willing to pay a premium to avoid this choice. ${ }^{56}$

Furthermore, the notion of "boundary effect" was developed. That is to say, the perception changes on the "edges" of the probability. For instance, when facing losses, ambiguous low probabilities are over-weighted and ambiguous high probabilities are underweighted. ${ }^{57}$ Thus, people tend to express ambiguityaverse behavior when dealing with low probabilities, and ambiguity-seeking behavior when dealing with high probabilities. ${ }^{58}$ Kip Viscusi and Harrell Chesson calculated empirically the "mean crossover point," where people turn from ambiguity averse to ambiguity seeking, to be somewhere between 0.40 0.49 .59 To be precise, when people face an ambiguous loss, yet estimate the probability to be lower than $40 \%$ they will exert ambiguity-averse behavior. ${ }^{60}$ Analogically, whereas individuals estimate the probability of occurrence to be higher than $49 \%$, they will tend to employ ambiguity-seeking behavior. ${ }^{61}$ Those results imply that ambiguity induces more compliance where the deterrence is weak (low probabilities of detection), and less compliance where the deterrence is strong (high probabilities of detection). This evidence is reassuring since most

${ }^{51} I d$.

${ }^{52}$ If there are a total of 100 balls, red and black, then the bets are mutually exclusive. Thus, the perception of $\mathrm{P}\left(\mathrm{B}_{\mathrm{B}}\right)>\mathrm{P}\left(\mathrm{B}_{\mathrm{A}}\right)$ should be followed by the assumption that $\mathrm{P}\left(\mathrm{R}_{\mathrm{B}}\right)<\mathrm{P}\left(\mathrm{R}_{\mathrm{A}}\right)$.

${ }_{53}$ Ellsberg, supra note 49 , at 650-51.

54 See Colin Camerer \& Martin Weber, Recent Developments in Modeling Preferences: Uncertainty and Ambiguity, 5 J. OF RISK AND UNCERTAINTY 325, 360 (1992).

${ }^{55}$ See generally Gideon Keren \& Leonie E.M. Gerritsen, On the Robustness and Possible Accounts of Ambiguity Aversion, 103 ACTA Psychologica 149, 155 (1999).

${ }^{56}$ See Selwyn W. Becker \& Fred O. Brownson, What Price Ambiguity? or the Role of Ambiguity in Decision-Making, 72 J. POL. ECON. 62, 73 (1964).

${ }^{57}$ See Hillel J. Einhorn \& Robin M. Hogarth, Decision Making under Ambiguity, 59 J. of Bus. 225, 247 (1986) (discussing a mirror situation as well, i.e. when people face gains they tend to overestimate ambiguous low probabilities and under-estimate ambiguous high probabilities).

${ }^{58} I d$. at 245.

${ }^{59}$ W. Kip Viscusi \& Harrell Chesson, Hopes and Fears: The Conflicting Effects of Risk Ambiguity, 47 THEORY \& DECISION 153, 173 (1999).

${ }^{60} \mathrm{Id}$.

${ }^{61}$ See id. 
of the crimes, which might be deterred by the following suggested means, have a low rate of detection. ${ }^{62}$

Whereas those findings are explored in the literature regarding the enforcement of tax evasion, ${ }^{63}$ its empirical investigation and application in the enforcement of other crimes are limited. A handful of studies suggest using ambiguity in the context of probability of detection and offer some empirical evidence to support their suggestions. ${ }^{64}$

Lawrence Sherman examines "crackdowns" (i.e. an increase in policing in certain areas for certain periods) in the U.S. during the 1980s and offers some suggestive evidence of a successful deterrence. ${ }^{65}$ The author demonstrates that sometimes the deterrence effect remains even after the 'crackdown' terminates, and names this effect "residual deterrence." Based on that, the author suggests that using short-period "crackdowns" in different places and times might be a cost-efficient policy. ${ }^{66}$

More than a decade later, Tom Baker, Alon Harel and Tamar Kugler tested empirically the efficiency of ambiguity as a deterrence effect. ${ }^{67}$ They pursued it by conducting a laboratory experiment with payoffs and the possibility for an action that might result in a fine. ${ }^{68}$ In this experiment the subjects were facing two options: Option A, in which they receive only the payoff for participation, or Option B, where they could receive an additional payment, yet, with the risk of paying a fine if detected choosing this option. An important fact is that Option B had higher expected value than Option A. Option B had different structures of uncertainty regarding the penalty and the probability of being punished. Some of the options were risky (i.e. unknown outcome, yet known probabilities), whereas others were ambiguous (i.e. the precise probability of being caught was unknown). The authors found that participants were better deterred by the ambiguous option of detection (or uncertain size of punishment) than by the risky one. ${ }^{69}$ To be precise, when facing an ambiguous detection probability, subjects had a tendency to prefer Option A to B even though the

${ }^{62}$ See infra notes 78-80 and accompanying text.

${ }^{63}$ See generally Michael W. Spicer \& J. Everett Thomas, Audit Probabilities and the Tax Evasion Decision: An Experimental Approach, 2 J. EcON. PsYcH. 241, 241 (1982); Jeff T. Casey \& John T. Scholz, Boundary Effects of Vague Risk Information on Taxpayer Decisions, 50 OrGAN. BEHAV. Hum. Dec. Processes 360, 360 (1991); Jeff T. Casey \& John T. Scholz, Beyond Deterrence: Behavioral Decision Theory and Tax Compliance, 25 LAW AND Society Rev. 821, 821 (1991); Dipankar Ghosh \& Terry L. Crain, Structure of Uncertainty and Decision Making: An Experimental Investigation, 24 DECISION SCI. 789, 789 (1993).

${ }^{64}$ See generally Sherman, supra note 15, at 1; Baker, Harel, \& Kugler, supra note 15, at 476-77; Loughran et al., supra note 15, at 1029-30.

${ }^{65}$ See Sherman, supra note 15 , at 1.

${ }^{66}$ See id. at 11-12.

${ }^{67}$ See Baker, Harel, \& Kugler, supra note 15, at 445.

${ }^{68}$ See id.

${ }^{69}$ See id. at 466. 
latter had a higher expected value. Furthermore, this effect was stronger when the uncertainty was greater..$^{70}$

Similarly, Thomas Loughran and others used, in a recent study, data from the Pathways to Desistance Study to follow the independent ${ }^{71}$ effect of ambiguity on young offenders. ${ }^{72}$ The authors found that for instrumental crimes $^{73}$ and lower perceived probability of detection (below 0.3 ), criminals are deterred by a stronger ambiguity. Namely, when the offenders perceived the probability of being detected as low, yet, could not estimate precisely this probability, they tended to commit fewer crimes. ${ }^{74}$ The main significance of this research lies in the chosen sample. Whereas the majority of the empirical studies demonstrate the phenomenon of ambiguity aversion on the general population, this research presents evidence that ambiguity has a negative effect also on actual criminals.

Another important caveat of the abovementioned study is that ambiguity has a deterrent effect when the perceived risk of being arrested is low. ${ }^{75}$ Crimes that are expected to be most affected by introducing ambiguity into probability of detection are "street crimes." The latter usually are property crimes ${ }^{76}$ and those are the crimes that can be deterred by police patrols. Property crimes often have low actual probability of detection. For instance, the German clearance rate of serious theft was around thirteen percent between the years 1998 - 2001, as compared to aggravated assault clearance rate, which was around eighty-five percent. ${ }^{77}$ Criminology literature assists to identify the correlation between the actual and the perceived probability of detection and suggests that criminals update upwards their probability of apprehension after being arrested. ${ }^{78}$

\footnotetext{
${ }^{70}$ See id. at 453-54.

71 See Loughran et al., supra note 15, at 1034, n.4 (examining the effect of ambiguity as independent from the effect of probability of detection).

${ }^{72}$ The Desistance Study is a longitudinal study of young criminals who were convicted for serious crimes. In this project, researchers were following during a period of seven years, the life changes of more than 1,300 juveniles in transition from adolescence into early adulthood. See A Study of Serious Adolescent Offenders as They Transition to Adulthood and Out of Crime, Pathways to DESISTANCE, http://www.pathwaysstudy.pitt.edu/ (last visited July 10, 2015).

73 "Instrumental crimes" are offences that are meant to achieve a certain goal, e.g. property crimes are usually committed in order to extract money from others. See William J. Chambliss, Types of Deviance and the Effectiveness of Legal Sanctions, 1 WIS. L. REV. 703, 708 (1967). "Expressive crimes" on the other hand, are committed for a pleasure and are ends by themselves. Id.

${ }^{74}$ See Loughran et al., supra note 15, at 1037.

${ }^{75} \mathrm{Id}$. at 1030 .

${ }^{76} \mathrm{Id}$. at 1055 (finding the effect of ambiguity on a group of crimes they name NOA ("no one around"), which consist of the instrumental/property crimes). See also MacDonald, Klick, \& Grunwald, supra note 34, at 17 (showing that the most statistically significant effect of police on reducing crimes is on the following crimes: auto theft, burglary, robbery with gun and theft from motor vehicles, i.e. property crimes).

${ }^{77}$ Entorf \& Spengler, supra note 25, at 177.

${ }^{78}$ See generally Shamena Anwar \& Thomas A. Loughran, Testing a Bayesian Learning Theory of Deterrence Among Serious Juvenile Offenders, 49 CRIMINOLOGY 667, 673 (2011). Worth mentioning is that the strength of updating depends how many crimes the criminal managed to
} 
Therefore, if only thirteen percent of criminals are arrested for their crimes, the majority of property crimes offenders might have low perceived probability of detection. Consequently, the results, which support a "boundary effect," imply that street crimes might be deterred by ambiguous detection policing.

The aforementioned studies offer empirical support for the deterrence effect of ambiguous probability of detection in the context of "regular" crimes. The following sections discuss detailed policy changes to introduce ambiguity into probability of detection. Furthermore, some evidence is presented to illustrate bounded rationality of potential violators. Forasmuch as awareness is an integral part of the ambiguity policy, methods to increase the saliency of the changed policy are analyzed.

\section{ANY-WHERE ANY-TIME: TOWARDS A NEW POLICY}

\section{A. Randomization of the Detection Strategies}

When police operate in a certain way, there is a pattern that the potential criminal can learn. It does not mean that police enforce crimes in completely predictable ways (e.g. patrolling in a specific place at the same day and the same hour), rather it refers to the fact that the crime monitoring techniques are based on some rationales which can be learned. With such policy, criminals are able to acquire information on the areas and times that are riskier in terms of being caught and the methods used by police for detection. ${ }^{79}$ Thus, they are facing an uncertain environment of being arrested, yet they can estimate the risk, and try to minimize it by selecting where and when to commit crimes. The general presumption is that criminals are risk seeking, ${ }^{80}$ thus, a mere probability of being detected, as long as it is not high, does not have a sufficient deterrent effect.

On the contrary, based on the empirical evidence reviewed in the previous section, eliminating the predictability of police work and turning the likelihood of being detected to ambiguous, might change criminals' behavior. The suggestion is to keep investigating crimes based on existing evidence, however, in addition, to create a very ambiguous and hectic environment in which the criminals are operating. This proposal stems from the distinction between monitoring and investigating methods. In the former, the enforcement authorities invest money in crime control prior to the offender's action, mainly to prevent crimes. ${ }^{81}$ In the latter, the police invest resources to collect evidence and

commit prior to being arrested. The lower the ratio of arrests to the number of committed crimes, the weaker is the updating strength of the current arrest. Id.

${ }^{79}$ See Loughran et al., supra note 15, at 1046 (presenting evidence that while criminals' perception of risk is increasing, the perception of ambiguity is decreasing, and suggesting that, with time, criminals gain more experience and can predict better their risks of being detected).

${ }^{80}$ See generally Becker, supra note 6, at 169.

${ }^{81}$ See Dilip Mookherjee \& I. P. L. Png, Monitoring vis-à-vis Investigation in Enforcement of Law, 82 Am. ECON. Rev. 556, 556 (1992). 
solve crimes which have been previously committed. ${ }^{82}$ Inasmuch as both methods are important in challenging crime, this paper does not offer to replace investigation, but to improve monitoring. The suggestions for the policy changes are as follows.

First, it is suggested to use deliberately random police patrols. ${ }^{83}$ Namely, the idea is to send police cars or police on foot to patrol in diverse areas, on different days. Those patrolling projects will also vary in the overall duration (e.g. for several consecutive days, a week, etc.). These police campaigns or crackdowns are common in the U.S., yet quite rare in the EU. The goal of this mechanism should be the creation of ambiguous perceived probability rather than occasionally targeting specific crimes or places due to a contemporary need. Since the agents who will be making the patrolling schedule might be unconsciously tempted to create a certain pattern, the schedule may be selected randomly by specifically designed computer software, once a week or once a month. Under these circumstances, the potential criminals will not be able to learn the patterns of police work, since there will not be any pattern to learn. Thus, not being able to calculate the risk of operating in a certain area, at a certain time, might enhance the deterrent effect.

An additional possible benefit of this kind of policy is the reduction of the "displacement effect." According to the latter, when some crime prevention measures are taken in a certain area, criminals merely displace their activity to other areas. ${ }^{84}$ Consequently, in terms of overall welfare there are no benefits to society, inasmuch as the same quantity of crimes is committed in a different place. Therefore, increasing constant police presence in specific areas is not only costly, but might displace the crime to other locations. On the contrary, sending random patrols to variant places for different time periods might avoid this effect. The reason is that potential criminals would not be able to know which areas are more risky for them. Thus, it will not seem beneficial to prefer one area to the other, and displace their criminal activity.

Bearing the above-mentioned in mind, more problematic areas should receive to a certain degree more police attention, even if randomly. This suggestion is relying on the concept of "targeted enforcement." the latter, when enforcement costs are limited, it is efficient to increase the probability of apprehension for violators who did not comply with the law in the past. ${ }^{86}$ Similarly, in the current context, places with generally higher crime rates

\footnotetext{
${ }^{82}$ See id.

${ }^{83}$ Random patrolling was briefly offered in the abovementioned studies discussing ambiguity and detection, however, its detailed structure and way of application were not explored, and are investigated in this study.

${ }^{84}$ See Rene B.P. Hesseling, Displacement: A Review of the Empirical Literature, RESEARCH \& DOCUMENTATION CENTRE 197, 213 (1994).

85 See Winston Harrington, Enforcement Leverage when Penalties are Restricted, 37 J. PuBLIC ECON. 29, 39-43 (1988).

${ }^{86}$ See id. at 48-49.
} 
should receive higher proportion of policing. For this purpose, police statistics of reported crimes may be used to identify those "hot spots." ${ }^{87}$ Nevertheless, police patrols should also be sent, albeit in smaller dosages, to less dubious locations in order to prevent the displacement effect. Thus, the proportion of patrols will be higher in more problematic areas, yet within those patrols the randomness will be kept. This element is important in order to maintain the unpredictability of the patrols and so not to create a particular pattern of work that can be identified.

The second suggestion concerns a later period of the policy. After a certain time frame where the police patrol would be patrolling with uniform, undercover policing will be introduced. ${ }^{88}$ This new change, as the rest of the policy, should be announced and brought to the attention of the potential criminals. From that point onwards, not only would the patrols themselves be random, but also the usage of uniform will be irregular. It is suggested however, to use to a lower extent undercover police since visibility by itself might have a deterrence effect. ${ }^{89}$ This adds another element of ambiguity. In those circumstances, the potential criminal is not only uncertain about the places and time where he can be caught, but also about the person who can apprehend him. In extreme cases it can even create a feeling that a potential victim might be a policeman. Consequently, this increased ambiguity might have a stronger deterrent effect.

It should be stressed that both police in uniform and without uniform would be allowed to act only within the limits of the law in each country. For instance, in criminal justice systems where there is a constraint on police intervention, they are granted the authority to stop, question, search, and arrest people only in those circumstances where there is a reasonable suspicion that a person is a potential or actual offender. ${ }^{90}$ This limitation would reassure one that law abiding people will not be harassed unnecessarily and harmed by the new policy.

Third, this paper suggests installing cameras $^{91}$ in different areas (only public locations). However, assuming activation of cameras imposes costs as

\footnotetext{
87 "Hot spots" are areas in which the rate of public disorder and crime is among the highest. Those locations often accommodate leisure and business activities which attract people and in turn, criminals who see the opportunity for a loot. See Christopher S. Koper, Just Enough Police Presence: Reducing Crime and Disorderly Behavior by Optimizing Patrol Time in Crime Hot Spots, 12 Justice QuARTERLy 649, 652-53 (1995).

${ }^{88}$ The reason not to introduce the undercover policing from the beginning is the benefits of visible police. At the first stage, the criminals can learn about the new random policing by seeing the police in different areas in different times. Only after they have learned about the new policy, it is worth introducing the additional element of ambiguity, i.e. undercover police.

${ }^{89}$ See, e.g., Jolls, Sunstein, \& Thaler, supra note 14, at 1538.

${ }^{90}$ In different countries, there are different rules guiding the police force in their work. The threshold for "reasonable suspicion" varies across criminal justice systems, thus, it should be adjusted to each system.

${ }^{91}$ See generally Wireless CCTV Systems, WCCTV, http://www.wcctv.co.uk/ (last visited July 19, 2015).
} 
well, it is offered to activate them randomly in different areas on different days. Alternatively, the new WCCTV cameras can be used. Those are movable, costefficient cameras, which do not require an infrastructure, thus, reducing the costs of installation. ${ }^{92}$ They can be quickly deployed at any location and moved to a different location at any time. This will introduce another element of ambiguity and randomize the monitoring enforcement methods while reducing the costs of operating the cameras. Furthermore, it might have the effect of police patrols, thus, enabling to cover wider range of areas.

The above measures should be combined with high publicity of the ambiguity to overcome people's bounded rationality and to intensify its effect as explained in the following sections.

\section{B. Policy and Awareness}

Merely changing the policy of detection to more ambiguous is insufficient for deterrence. One of the criticisms that can be found in the criminology literature regarding crime control policies is that without a proper link between the rule and the awareness of criminals, offenders are resistant to policy changes. ${ }^{93}$ As discussed in section two, people have bounded rationality and do not possess complete information. Thus, criminals might not really recognize changes in the enforcement policy. The following survey illustrates this problem.

\section{The Example of the Tax Rule in Italy}

Tax evasion is a common problem in some countries with Italy being in a forefront on that matter. ${ }^{94}$ One of the targeted groups for the tax authorities is the shopkeepers. The cost of monitoring are high since sellers may simply refrain from issuing receipts, thus, presenting to the tax authorities a lower income than actual. In order to solve this problem and incentivize merchants to issue tax receipts, in 1983 the Italian government introduced a new law. ${ }^{95}$ According to this law, sellers who failed to provide a receipt after each sale faced a fine. ${ }^{96}$ Moreover, in an innovative step, an additional provision was introduced which obligated the consumers to ask for a receipt after completing their purchase. ${ }^{97}$ In other words, if a buyer purchased a good and left the shop without a receipt, the

\footnotetext{
${ }^{92}$ See id.

${ }_{93}$ Nagin, supra note 47, at 18.

94 Richard Murphy, The Cost of Tax Abuse: A Briefing Paper on the Costs of Tax Evasion Worldwide, Tax Justice Network (2011).

${ }^{95}$ Legge 15 febbraio 1983, n.18 (It.).

${ }^{96}$ L. n.18/1983 s 1 (It.).

${ }^{97}$ L. n. $18 / 1983$ s 2 (It.).
} 
authorities could impose a fine on the buyer (hereinafter: "The Tax Policy").98 This law was enforced - with low probability - by the Guardia di Finanza (Fiscal Police). ${ }^{99}$ Through the years the law was reformed and eventually abolished in 2003. ${ }^{100}$

\section{The Survey}

The uniqueness of the abovementioned violation (relevant to buyers) is that anyone in the population is a potential violator. Forasmuch as most people, if not all, purchase goods during the course of their life, the law requiring consumers to ask for a receipt has a wide applicability. Therefore, investigating the awareness of the ordinary population regarding this tax policy and its changes may be considered as having an external validity.

The purpose of the survey was to assess whether Italian citizens were aware of the introduction of the tax policy and whether they knew this policy was abolished in 2003. To this end, two surveys in the Italian language were prepared and distributed between two samples of the Italian population. The surveys included ten questions, some referring to general characteristics, whereas others are questions of interest. The first question of interest refers to the awareness of the respondents to the fact that the tax policy was abolished (question number four). The second question of interest examines whether people knew of the introduction of the policy in the first place (question ten). Other questions explore the source of information, whether people comply/complied with the law, their knowledge regarding apprehended violators, and whether they knew what the expected punishment for this violation was. For the full questionnaires, see Appendix B.

One of the two main questions of interest (question four) differs between the two surveys in order to assure the results are independent of the formulation of the question. In the first survey (Survey One), the main question of interest is as follows, "According to the current Italian law, are buyers in Italy obliged to take a receipt after making a purchase of any kind?" In the second survey (Survey Two), the question is formulated in the following way, "According to the current Italian law, are CONSUMERS obliged to ask for a receipt after making a purchase of any kind?" The two samples differ in the characteristics of the respondents (for summary statistics see Table A1 in Appendix A).

${ }^{8}$ See Roderick Conway Morris, Whenin Italy, Keep That Receipt!, N.Y. TimES (Apr. 10, 1992), http://www.nytimes.com/1992/04/10/style/10iht-rece_0.html.

${ }^{99}$ See id.

100 See Stefano Filippi, Il Falso Spauracchio Dello Scontrino:per Legge Il Cliente Non Rischia Nulla, IL GiORNALE (Jan. 7, 2012), http://www.ilgiornale.it/news/falso-spauracchio-delloscontrinoper-legge-cliente-non.html. 


\section{Results}

The results demonstrate lack of awareness mainly with regard to the abolishment of the tax policy, but also of its initial introduction as well. ${ }^{101}$ In Survey One, around eighty-four percent of the respondents were either not aware the tax policy was introduced or that it was abolished. ${ }^{102}$ Moreover, seventy-two percent of the respondents, who believed the tax policy exists nowadays, stated they are still complying ${ }^{103}$ with this policy.

The results in Survey Two are mostly analogous to Survey One. About eighty-three percent of the respondents either stated the tax policy currently exists or that it was never introduced. ${ }^{104}$ Furthermore, seventy-eight percent of those who were not aware of the abolishment of the tax policy suggested they currently comply with it. ${ }^{105}$

Interestingly, the results demonstrate that media is an important source of information regarding the existence of the tax policy in both surveys. Furthermore, the results suggest the respondents are quite well informed regarding the prescribed punishment for this violation (for the complete results of the two surveys see Table A1 in Appendix A).

\section{Limitations}

The two samples are not randomly depicted from the Italian population hence it might be argued that they are not representative of the entire population. Nevertheless, there is still some variation in age, levels of education, and living area of the respondents. Furthermore, the discussed tax policy is relevant to all the respondents in the two samples, as much as it is relevant to the general Italian population. Therefore, it is asserted that those results have an application beyond the sample.

\section{Discussion}

The results of the survey are striking and suggest, contrary to the rational choice theory, that potential violators might indeed have bounded rationality. To be precise, the abovementioned results suggest people are not perfectly informed of policy changes made by the authorities. In the example of the Italian tax policy, the majority of the respondents are not aware that the policy, which

\footnotetext{
${ }^{101}$ See infra Table A1, Appendix A.

102 Id.

${ }^{103} I d$. One concern might be that people do not reveal their true behavior believing they are breaching the law. However, since the survey is anonymous and the respondents are clearly informed about this before providing their answers, this might not be a significant problem.

${ }^{104} \mathrm{Id}$.

${ }^{105} I d$.
} 
threatens them with a fine, no longer exists. Some of those people not only lack the awareness, but also in fact comply with a non-existent law.

Inasmuch as the suggested policy in this paper targets offenders' awareness of the ambiguity, it is of outmost importance to guarantee they are familiar with the changes in the enforcement methods. Otherwise, the introduction of ambiguity might have little or no effect on crime. For this reason, and following the presented findings of the survey, the current section discusses the availability heuristics and the ways to increase criminals' awareness of the suggested policy, which in turn is expected to intensify its effect.

\section{Increasing Awareness through Availability Heuristics}

Amos Tversky and Daniel Kahneman discussed the rules-of-thumb people use while judging frequencies and probabilities. ${ }^{106}$ The world is uncertain and people often face the need to assess the probability or frequency of an event. ${ }^{107}$ Since on the one hand, there is a great deal of information which needs to be processed and, on the other hand, not all the relevant information is available, people use life experience in order to develop mechanisms to cope with this reality. For instance, people know that it is easier to recollect high frequency events compared to rare events. ${ }^{108}$ In addition, more likely events are perceived as easier to imagine. Lastly, there is a stronger associative connection when two events frequently occur together. ${ }^{109}$

The abovementioned experiences lead to the rule-of-thumb of "availability" - the assessed frequency or likelihood of an event depends on the simplicity with which it can be retrieved from one's mind. Although useful, availability is not always a valid tool since it is influenced by other factors that might be unrelated to the actual frequency of an event. Hence, the usage of this short cut leads to systematic biases. For instance, a person might assess the frequency of divorce based on the rate of divorce among his acquaintances. Not surprisingly, this estimation might be different from the actual frequency and only by chance is this person acquainted with a great deal of divorced couples. ${ }^{110}$

The availability heuristics has an effect in many areas of life, and has already been analyzed in the context of criminal law. ${ }^{111}$ The behavioral approach does not follow the concept that potential criminals are fully rational and make decisions based on complete and accurate information. ${ }^{12}$ Still, it is rather accepted that offenders make some calculations of expected costs and benefits of

\footnotetext{
${ }^{106}$ See generally Tversky \& Kahneman, supra note 16, at 207.

107 See id.

108 See id. at 208.

${ }^{109} \mathrm{Id}$.

${ }^{110} \mathrm{Id}$.

${ }^{111}$ See Jolls, Sunstein, \& Thaler, supra note 14, at 1545.

${ }^{112} \mathrm{Id}$. at 1538 .
} 
crime. However, due to their bounded rationality, potential criminals might assess the probability of the expected punishment based on the availability of the relevant information to them. Inevitably, this information may be not related to the actual probability and thus, lead to mistaken judgment. ${ }^{113}$

Nonetheless, the abovementioned biases are believed to be systematic as opposed to random. Thus, Jolls, Sunstein, and Thaler suggest making enforcement policy more visible. ${ }^{114}$ For instance, instead of using small and less costly parking tickets, they offer to place noticeable colored parking tickets with the word "VIOLATION" on side window shields. ${ }^{115}$ They assert that this kind of policy would deter forbidden parking more efficiently by making the punishment very visible and available for others to see. ${ }^{116}$ In addition, they suggest using "community police" who will be patrolling streets by walking rather than driving. ${ }^{117}$ This makes the police more visible, and as a result might deter potential criminals without altering the actual probability of detection. ${ }^{118}$

In this paper it is suggested to make visible and salient the randomness of the detection rather than its probability per se. The problem in manipulating the perceived probability of detection lies in the famous question presented by Gordon Tullock: "Can you fool all of the people all of the time?"119 This kind of policy might have a too short-term effect. Since the actual probability is held constant, not much time will pass before the potential criminals would realize what is made available to them is not a representation of the actual risk of apprehension and, all the more so, in light of the known learning process people are going through in new circumstances. The latter would assist potential offenders to update their perceived probability of apprehension and cease responding to the manipulation.

Thus, it is suggested not to merely deceive offenders regarding the state of the world but to create an environment in which they are not capable of estimating their apprehension probabilities, and make them constantly aware of this. This might be achieved by publicizing the measures presented in Section III.A, and stressing the fact that unlike before, those measures are used in a random manner without a concrete pattern and that any offender can be apprehended at any time. It might even be useful to give this policy a "catchy" name such as "any-where any-time" policy that might be better kept in mind and in turn, more easily recollected.

\footnotetext{
${ }^{113} I d$.

${ }^{114} I d$.

${ }^{115} \mathrm{Id}$.

${ }^{116} I d$.

${ }^{117} \mathrm{Id}$.

${ }^{118} I d$.

119 Gordon Tullock, Comment, Can You Fool All of the People All of the Time?, 4 J. OF MonEY, CRedit AND BANKING 426, 426 (1972).
} 
Furthermore, the publicity should be made through all possible channels to cover a higher percentage of the criminal population. Namely, different forms of media should be used, short "advertisements" on television, in newspapers, whether online or in print, billboards on the roads, in public transportation stations, etc. In addition, occasionally some arrests should be publicized to emphasize that this policy actually detects criminals. The role of the press in people's awareness is captivatingly described by Bernard Cohen: "It may not be successful much of the time in telling people what to think, but it is stunningly successful in telling its readers what to think about." ${ }^{120}$ Therefore, the new policy would be thought and spoken about and would consequently reach criminals' consciousness directly and indirectly through hearing people talking about it on the streets.

Since the media might have different interests than law enforcement authorities, the latter should become "availability entrepreneurs." Availability entrepreneurs are people or organizations that are using the availability heuristics to promote their interests, such as firms in the private sector or lobbyists trying to advance certain regulations. One famous example of promotion of laws using the availability heuristics is the Love Canal example. ${ }^{21}$ With the help of an "availability entrepreneur" who used media and political pressure, a law was passed, state budget was wasted, and negligible environmental problems became a number one hazard. ${ }^{122}$ This anecdotal example demonstrates the powerful effect availability has on human behavior. ${ }^{123}$

Another somewhat different example is the lobbying strategy of the new Supreme Court of Mexico established in 1994. In order to restore people's trust in the government, the Mexican officials made extensive reforms to the judicial system. ${ }^{124}$ As a result of lack of media coverage, however, society was not properly aware of the reforms and kept perceiving the Supreme Court as submissive to the executive power and inaccessible to most people. ${ }^{125}$ In order to correct this perception and enable promotion of Court's interests, the latter pursued a publicizing strategy to raise the awareness of people to the new reforms. ${ }^{126}$ This was done through the Court's own Office of Public Relations (DCS). ${ }^{127}$ The latter was advertising announcements regarding the court's autonomy, and publishing books, leaflets, comics, and videos of the Court's most

\footnotetext{
${ }^{120}$ Bernard C. Cohen, The Press And Foreign Policy 13 (1963).

121 Timur Kuran \& Cass R. Sunstein, Availability Cascades and Risk Regulation, 51 StAN. L. REV. 683, 691-98 (1999).

${ }^{122}$ Id. at $692,696$.

${ }^{123} \mathrm{Id}$. at $692-93$.

${ }^{124}$ See Jeffrey K. Staton, Lobbying for Judicial Reform: The Role of the Mexican Supreme Court in Institutional Selection, 6-8 (UC San Diego: Center for U.S. Mexican Studies, Working Paper, 2003), http://www.escholarship.org/uc/item/30s2s2xj.

${ }^{125} \mathrm{Id}$. at 8 .

${ }^{126} \mathrm{Id}$. at $8-9$.

${ }^{127}$ Id. at 8-9.
} 
prominent decisions. ${ }^{128}$ Furthermore, the DCS issued routine press releases on pending and resolved cases. ${ }^{129}$ Some suggestive evidence demonstrates the success of this approach in promoting further judicial reforms. ${ }^{130}$

Therefore, this paper suggests that it might be efficient for enforcement authorities to act as "availability entrepreneurs," through its own Public Relation Office for example. The latter will ensure raised awareness of potential offenders to the new "any-where any-time" policy. This in turn, would intensify the effect of ambiguity-aversion and increase deterrence.

\section{POSSIBLE LIMITATIONS}

Even if criminals are indeed averse to ambiguity, there are some possible limitations of the policy that are addressed in the following sections.

\section{A. Limited Expected Scope of Effect}

The suggested policy is expected to affect "street crimes" rather than all crimes. Namely, crimes that are usually committed indoor most probably will not be deterred by these policy changes.

There are a number of possible replies to this limitation. First, many of the street crimes are property crimes (e.g. car theft, theft from car, burglaries, etc.). In many countries property crimes constitute a large portion of total crimes. $^{131}$ For instance, in Germany in 2002, around 50\% of all reported crimes were theft. ${ }^{132}$ Thus, a policy that has the potential to deter this type of offense may reduce significant costs of crime.

Second, this paper suggests that a policy which targets different groups of crimes with different methods rather than offering a unified policy for all crimes might be more efficient. The rationale behind this suggestion is that different groups of crimes have special characteristics. ${ }^{133}$ In turn, the responsiveness to law enforcement of criminals from these groups varies. Thus, instead of attempting to capture all criminals with one policy, it might be more efficient to think of different policies for different crimes.

\footnotetext{
${ }^{128} I d$. at 9 .

${ }^{129} \mathrm{Id}$. at $8-9$.

${ }^{130} \mathrm{Id}$. at 10.

${ }^{131}$ In the US, in 2012, around $13,111,940$ people reported being victims of property crimes. This may be compared to $3,575,900$ people who reported being victims of violent crimes or 1,271,770 victims of serious violent crimes. See Jennifer L. Truman \& Lynn Langton, Criminal Victimization, 2013, Bureau of Justice Statistics 4 (2014).

${ }^{132}$ Cornelius Nestler, Sentencing in Germany, 7 Buff. Crim. L. Rev. 109, 114 (2003).

${ }^{133}$ Chambliss, supra note 73, at 712-17.
} 
For instance, Isaac Ehrlich discusses in his paper the efficiency of discriminating penalties. ${ }^{134} \mathrm{He}$ asserts that since some groups of criminals cannot be deterred, enforcement authorities should incapacitate them rather than trying to deter them. ${ }^{135}$ On the other hand, offenders who are responsive to enforcement should be dealt with using methods that are meant to deter crime. ${ }^{136}$

\section{B. Existing Level of Ambiguity}

Some scholars assert that there is already an element of ambiguity in the enforcement system. Thus, the question arises, what is the contribution in introducing the ambiguity using the measures described in the previous section?

In order to offer a possible response to this limitation, different examples where ambiguity already exists should be examined. Anat Horovitz and Uzi Segal review some of those existing policies. ${ }^{137}$ First, the most famous mechanisms used to create uncertainty are fake cameras and dummy police cars in the area of traffic control. ${ }^{138}$ This is indeed a useful mechanism in order to create ambiguity in the detection probability, however, it is limited to traffic control and does not extend to the "street crime" control. The second example is random searches at airports. ${ }^{139}$ The authors present this policy as an illustration for the existing ambiguity, yet they explain that the deterrence achieved "by inspecting people and goods according to their 'assessed level of risk,' which is based on factors undisclosed to the public." ${ }^{140}$ The fact that the authorities do not disclose their assessment techniques does not make the policy random. Once the enforcement authorities target suspects by "assessed level of risk," there is a pattern that might be evaluated by the potential "offender" and remove the ambiguity element from the searches. Consequently, those searches will remain random only for the "innocents" who are not interested in understanding the undisclosed techniques. The third example is random tax auditing. Nevertheless, the authors do not assert it is random, rather they say that the tax authorities audit only a certain portion of all tax returns. ${ }^{141}$ Therefore, whereas tax audits usually have low probability, it is not necessarily random.

The above analysis demonstrates that although there is already an attempt to increase ambiguity of the enforcement methods, it is usually restricted to specific areas. Furthermore, from the description of "crackdowns" by

\footnotetext{
134 See Isaac Ehrlich, On the Usefulness of Controlling Individuals: An Economic Analysis of Rehabilitation, 71 AM. ECON. REV. 307, 307 (1981).

${ }^{135} \mathrm{Id}$. at 314-16.

${ }^{136} \mathrm{Id}$. at 319.

137 See Anat Horovitz and Uzi Segal, The Ambiguous Nature of Ambiguity and Crime Control, 2 NYU J.L. \& LIBERTY 541, 542 (2007).

${ }^{138} \mathrm{Id}$. at 555

${ }^{139} \mathrm{Id}$. at $555 \mathrm{nn} .28-29$.

${ }^{140} \mathrm{Id}$. at $555 \mathrm{n} .28$

${ }^{141}$ Id.
} 
Sherman, ${ }^{142}$ it seems that the police campaigns have a pattern as well and they cannot be accounted as truly random. Moreover, studies on the ambiguity aversion demonstrate that the higher the ambiguity, the stronger is the ambiguity aversion. ${ }^{143}$ Therefore, it is suggested that creating or increasing the level of ambiguity in the detection policy using the described instruments might increase the deterrence effect.

\section{Learning Process}

Offenders, as other people, are going through a learning process in which they adjust to new circumstances. Thus, possible counterargument to the suggested policy might be that even if offenders are currently ambiguity averse, in time they will adjust to the new methods and the deterrent effect will diminish.

Nevertheless, this argument holds for any enforcement policy, even for the current one. If indeed offenders go through a learning process, this implies that they are already fully adjusted to the existing policy of detection. Thus, changing the current policy may improve the deterrence by introducing new circumstances to which the offenders still have not adjusted.

\section{Possible Infringement of Civil Rights}

Another possible challenge to the suggested policy might be that it will infringe upon the civil rights of law-abiding people. In addition, publicizing such a policy may create a feeling of "state-police" and restrict people's selfexpressing behavior. This, in turn, might lead to a loss of trust in the enforcement authorities.

There are a number of possible responses to this concern. First, the suggested policy is analyzed for application in countries with a democratic regime. Those countries usually have strong safeguards of civil and human rights. Thus, a proper system of checks and balances will be in force. Furthermore, an informal body is already active in many of those countries, i.e. Ombudsman, ${ }^{144}$ enabling civilians to file complains on police misconduct. For instance, if minorities experience discrimination or harassment by police officers under this policy, these victims may file a complaint to the Ombudsman.

In addition, the police will be acting within the existing limits of power and under the rule of law. For instance, in countries where only those who exhibit suspicious behavior are followed by police intervention, these same

\footnotetext{
142 See Sherman, supra note 15.

${ }^{143}$ Viscusi \& Chesson, supra note 59, at 155; see also Camerer \& Weber, supra note 54, at 325-26. 144 Gabriele Kucsko-Stadlmayer, European Ombudsman-InStitutions: A Comparative Legal Analysis Regarding the Multi-faceted Realisation of an Idea,1-167 (Gabriele Kucsko-Stadlmayer ed., 2008).
} 
people will also be the only ones to be addressed under the new policy. Police will not be allowed to interrupt the lives of law-abiding people. Thus, the new policy, which will monitor people randomly, is not expected to infringe civil rights more than the current policy. Consequently, as people will not be harassed in vain, there probably will not be a loss of trust in the enforcement authorities.

A second possible response is that for law-abiding people the current regime is already random. As discussed before, offenders might know the pattern of police work inasmuch as it concerns their risk of being detected. They are incentivized to learn the patterns of police force and reduce the uncertainty of committing crime. On the contrary, law-abiding citizens usually do not spend time studying the patterns of police work. They also do not learn it passively by being arrested. For this part of the society, as long as police are not present everywhere, their presence is random. Consequently, introducing ambiguity into the probability of detection by converting police monitoring work to random activity should only affect criminals.

\section{E. Legitimacy}

A similar, albeit separate, counterargument for the suggested policy is the possible lack of legitimacy in randomizing police work. For instance, in the U.S. the tax authorities, the Internal Revenue Service (IRS), introduced random auditing. ${ }^{145}$ Under the new policy, people were audited at random rather than according to some calculations that chose suspicious people for auditing. ${ }^{146}$ Honest taxpayers challenged the legitimacy of this kind of policy due to the inconvenience of being audited. ${ }^{147}$ In addition, their argument was that instead of following an efficient "formula" which selects suspicious people for auditing, law-abiding people were harassed by the IRS authorities. ${ }^{148}$

As mentioned previously, the suggested policy addresses the monitoring methods, while offering to keep the investigating methods intact. Namely, police will continue investigating committed crimes based on existing evidence ("formula"), thus, not disregarding actual suspects. Whereas regarding the legitimacy of making monitoring random, a possible response rests in the legitimacy of the current policy. As long as there is no absolute police presence, the areas patrolled under regular policy are limited, which means the other areas are discriminated against. This is done, however, based on contemporary needs, e.g. calls for assistance or more problematic areas. As explained previously, the problematic areas would still receive special attention, yet, in a random manner.

145 IRS Audits, Internal Revenue SERvice, http:/www.irs.gov/Businesses/Small-Businesses-\&Self-Employed/IRS-Audits (last updated July 10, 2015). I would like to thank Jeffrey Rachlinski for this constructive example.

${ }^{146} \mathrm{Id}$.

${ }^{147} \mathrm{Id}$.

${ }^{148} I d$. 
Furthermore, the fact the new policy would also cover other areas might even increase the legitimacy of monitoring decisions. The reason for that is minimization of the crime displacement risk. Thus, there is a rationale justifying the new policy, and in turn, increasing its legitimacy.

\section{F. Contrasting Biases}

A somewhat different counterargument against the suggested policy is that there are other biases, which may work in the opposite direction and distort the effect of ambiguity aversion. One such bias is overconfidence. ${ }^{149}$ Criminals might be overconfident regarding their chances to escape the enforcement authorities and hence, not be deterred by the new policy.

Nevertheless, despite this bias, the policy might still be effective. First, as suggested by Nuno Garoupa, the same overconfidence bias also leads those offenders to take fewer precautions to escape from the law enforcement that makes their detection easier. ${ }^{150}$ Second, the suggested policy does not deal with the probability of detection as such, but with ambiguity aversion of criminals. Namely, whereas offenders might underestimate their probability of being apprehended in regular circumstances, the new policy will attempt to eliminate their sense of capacity to know those probabilities. Third, the empirical evidence suggesting there is a deterrence effect implies that the overconfidence problem is not so burdensome. Otherwise, since the actual probability of getting punished is almost never approaching one hundred percent, with vast overconfidence one should observe a very weak or non-existing deterrence effect.

\section{G. Comparative Ignorance Hypothesis}

Craig Fox and Amos Tversky challenged the ambiguity aversion phenomenon and proclaimed that its effect exists only in a comparative setting. ${ }^{151}$ That is, people express ambiguity aversion in circumstances where they have a choice between clear and vague prospects. ${ }^{152}$ On the contrary, evaluation of an uncertain event in isolation from other choices leads to assessment of its likelihood while disregarding the vagueness of the event. ${ }^{153}$ The authors called this phenomenon "comparative ignorance hypothesis" and supported it with experimental evidence. ${ }^{154}$

\footnotetext{
${ }^{149}$ See McAdams \& Ulen, supra note 12, at 17.

${ }_{150}$ Nuno Garoupa, Behavioral Economic Analysis of Crime: A Critical Review, 15 Eur. J. LAW ECON. 5, 9 (2003).

${ }^{151}$ Craig R. Fox \& Amos Tversky, Ambiguity Aversion and Comparative Ignorance, 110 Q. J. ECON. 585, 585 (1995).

$152 I d$.

${ }^{153} \mathrm{Id}$. at $587-88$.

${ }^{154} \mathrm{Id}$. at $585,588-98$.
} 
Relying on the comparative ignorance hypothesis, one might argue that introducing ambiguity aversion into the probability of detection would not affect potential criminals. However, there might be two possible replies to this counterargument. First, as discussed previously, Lougharn, et al. present empirical evidence that real offenders are ambiguity averse in the context of their decision whether to commit a crime. ${ }^{155}$ On the one hand, a conceivable explanation might be that the results of Fox and Tversky are relevant only in the context of gains, while in cases where people face expected losses (as criminals do) there is ambiguity aversion even in a non-comparative setting. ${ }^{156}$ On the other hand, a possible account of the results might be that due to a learning process, offenders perceive their choices (vague vs. risky) as comparable. ${ }^{157}$

Second, even under the assumption that the effect is stronger in a comparative prospect, it is possible to publicize the new ambiguous monitoring policy while framing it as a comparative policy. To be precise, the new policy might be presented as a transformation from risky apprehension to random police methods, which no longer can be predicted. As a result, it might intensify the ambiguity aversion effect and serve as a crime deterrence mechanism.

\section{CONCLUDING REMARKS AND OUTLOOK}

The probability of apprehension and punishment plays an important role in crime deterrence. This component includes the efficient function of different enforcement agents, i.e. police, prosecution, courts and lastly, correction agencies. ${ }^{158}$ Even though the severity of the imposed punishment is relevant in the crime control discussion, it seems as if it has a less significant impact on criminals. Consequently, the discourse on the enforcement policy should focus on the efficiency of agents involved in controlling the probability of detection and punishment.

Police force is the first authority to respond to crime. They are responsible to initiate the action of the law enforcement system. In order to enable the other agents to act against misconducts, they need to commence monitoring and investigation ${ }^{159}$ of crimes. While other stages are important as

\footnotetext{
${ }^{155}$ Lougharn et al., supra note 15, at 1029-30.

${ }^{156}$ In their paper, Fox and Tversky, supra note 151, framed all the experiments as gains. The Prospect theory suggests however, that people have different preferences when facing gains or losses, Kahneman and Tversky, supra note 42. Thus, it is suggested that people might be ambiguity averse even without a comparative setting once it is framed as a loss.

${ }^{157}$ It is probable that during criminals' "career" the perceived probabilities of apprehension are becoming more certain. Hence, they are acting in a comparative world where they may prefer the clearer event of risk as compared to the initial vague situation.

${ }^{158}$ In this paper, "correction agencies" refers to the authorities in charge of executing the imposed sanctions, whether it is imprisonment, collection of fines, or other sanctions.

${ }^{159}$ In some of the EU countries, prosecution has a considerable role in the investigation of crimes once they were reported or discovered by the police.
} 
well for crime control, police is the inevitable first phase without which the enforcement system cannot begin to function. This notion is supported by empirical evidence, discussed in this paper, which demonstrate the effect of the police on crime.

Despite its importance, it is not an easy task to increase police efficiency. It entails high tangible and social costs. Forasmuch as enforcement authorities act within a limited budget, this concern cannot be disregarded, all the more so when countries face crisis, such as the EU fiscal turmoil. Thus, this paper discusses the possibility of introducing somewhat different policing methods in order to enhance deterrence while saving costs of constant police presence.

The suggested policy changes are based on the behavioral law and economics approach and on empirical evidence supporting the fundamental elements of this policy. Distinct from the classic assumption of the rational agent, the behavioral approach recognizes the limitations in the human cognition. In accordance with this approach people have bounded rationality and when facing uncertain decisions, they tend to apply rules of thumb. The latter, albeit useful to cope with the cognitive limitations, might lead to erroneous judgments. Yet, those errors are systematic, and thereby, predictable.

In the past decades behavioral scholars discussed the relevance of heuristics and biases in the criminal framework. They assert that even though offenders' perception of risks is influenced by heuristics, they still make some assessments of costs and benefits. Therefore, behavioral studies focus on analyzing which and how those heuristics might affect criminal conduct. Nevertheless, the question in what manner heuristics influence offenders is not the only interesting inquiry in the context of criminal law. The next step should be investigating the possibilities in which these findings may assist in designing a better crime control policy, and this is attempted in this paper.

Vast empirical evidence has established the notion that people are ambiguity averse, and tend to avoid choices that are uncertain to them. This phenomenon has been extended also to the framework of criminal law. Subsequently, a few studies offer to introduce ambiguity into the probability of detection, and present empirical evidence that this uncertainty has a deterrent effect. In contribution to these studies, this paper elaborates on the structured policy changes which would introduce ambiguity into the probability of detection. Furthermore, the present paper presents evidence that potential violators in the tax policy area are not aware of policy changes. Forasmuch as awareness is crucial for the efficiency of ambiguity in deterring crime, this kind of problem needs to be addressed. Therefore, this study discusses the ways to use availability heuristic in order to increase criminals' awareness of the new policy. Finally, this study carefully deliberates possible limitations of this type of policy and attempts to reconcile those objections. There is a scope for further research of the costs of publicity and its optimal usage. 


\section{APPENDIX A}

Table A1: Survey Results

\begin{tabular}{|c|c|c|}
\hline Variable & Survey 1 & Survey 2 \\
\hline Number of respondents $N$ & 76 & 139 \\
\hline \multicolumn{3}{|l|}{ Age } \\
\hline Average age & 36 & 40 \\
\hline Min. Age & 20 & 19 \\
\hline Max Age & 63 & 65 \\
\hline \multicolumn{3}{|l|}{ Maximum education level } \\
\hline High school & $17 \%$ & $21 \%$ \\
\hline University & $83 \%$ & $77 \%$ \\
\hline Other & - & $1 \%$ \\
\hline Gender (\% of Male) & $53 \%$ & $72 \%$ \\
\hline \multicolumn{3}{|l|}{ Area (most of life) } \\
\hline North Italy & $64 \%$ & $69 \%$ \\
\hline South Italy & $31 \%$ & $30 \%$ \\
\hline Outside Italy & $5 \%$ & $1 \%$ \\
\hline \multicolumn{3}{|c|}{ Existence of the policy nowadays } \\
\hline Yes & $83 \%$ & $72 \%$ \\
\hline \multicolumn{3}{|l|}{ Source of Information* } \\
\hline Family & $22 \%$ & $20 \%$ \\
\hline Friends & $11 \%$ & $6 \%$ \\
\hline Media & $23 \%$ & $39 \%$ \\
\hline School or University & $8 \%$ & $7 \%$ \\
\hline Other & $30 \%$ & $29 \%$ \\
\hline \multicolumn{3}{|c|}{ Punishment for Non-Compliance* } \\
\hline Warning & - & $5 \%$ \\
\hline Fine & $80 \%$ & $86 \%$ \\
\hline Prison & $2 \%$ & $1 \%$ \\
\hline Community Service & - & $1 \%$ \\
\hline Probation & - & - \\
\hline Other & $2 \%$ & $2 \%$ \\
\hline Do not Know & $9 \%$ & $6 \%$ \\
\hline \multicolumn{3}{|c|}{ Knowledge about the rate of detection* } \\
\hline None & $69 \%$ & $74 \%$ \\
\hline 1 & $14 \%$ & $14 \%$ \\
\hline $2-10$ & $9 \%$ & $9 \%$ \\
\hline 11 or more & - & $3 \%$ \\
\hline \multicolumn{3}{|l|}{ Compliance* } \\
\hline Friends Comply & $58 \%$ & $51 \%$ \\
\hline Self-Compliance & $77 \%$ & $78 \%$ \\
\hline
\end{tabular}




\begin{tabular}{|c|c|c|}
\hline Existence of the law in the past*** & & \\
\hline No & $8 \%$ & $56 \%$ \\
\hline
\end{tabular}

Source: This table is a summary of the data collected and analyzed by me through a survey.

Note: Only the people who stated that the policy currently exists were required to answer the questions marked with *. Therefore, the percentage presented in the table regarding these questions is the number of respondents choosing this option/the number of respondents who answered this question. The results of the last question, marked $* *$, refer to the respondents who said the law did not exist/the responded who stated the law does not exists now.

\section{APPENDIX B}

\section{Original - Survey 1 (and in brackets the changes made in Survey 2): ${ }^{160}$}

Questo sondaggio ti farà delle domande riguardo a una particolare legge italiana. $\mathrm{Ci}$ sono nove domande e ti richiederà approssimativamente due minuti per completarlo. Le risposte che darai in questo sondaggio sono anonime e saranno usate solo in forma aggregata (il che significa che le risposte non verranno esaminate una per una, ma saranno prese in considerazione le risposte di tutti coloro che parteciperanno al sondaggio). Non verrai identificato in alcun modo per le risposte che darai. I dettagli demografici come l'età, sono raccolti sono con lo scopo di determinare tendenze generali riguardo ai dati, non per identificarti. Per assicurare che le tue risposte sono assolutamente confidenziali, il codice IP (il codice che è unico per ogni computer) non sarà collegato ai dati. Grazie per il tuo contributo a questa ricerca.

Se tu fossi interessato a ricevere i risultati generali di questo sondaggio o per qualsiasi domanda riguardo all'argomento scrivi a

1. Quanti anni hai e Qual è il tuo livello di istruzione? (per esempio: 22, scuola superiore)

2. Genere

(1) $\mathrm{F}$

(2) $\mathrm{M}$

3. In quale area geografica italiana hai vissuto maggiormente?

(1) Nord Italia

(2) Sud Italia

\footnotetext{
${ }^{160}$ The survey was prepared by the author and translated with the help of Anna Barbanti.
} 


\section{(3) Fuori dall'italia}

4. In accordo con l'attuale legge italiana, ci sono in Italia consumatori obbligati a prendere una ricevuta (scontrino) dopo aver fatto un acquisto di qualunque genere?

[Survey 2: In accordo con l'attuale legge italiana, i CONSUMATORI sono obbligati a richiedere una ricevuta (scontrino) dopo aver fatto un acquisto di qualunque genere?]
(1) $\mathrm{Si}$
(2) No

Se ha risposto "SI" alla domanda 4, continui a rispondere alle domande da 5 a 9 , altrimenti passi direttamente alla domanda 10 .

5. Come sei venuto a conoscenza di questa legge?
(1) Famiglia
(2) Amici
(3) Telegiornale
(4) Scuola o università
(5) Altri

6. Qual è la massima pena per non aver rispettato questa legge/regola?

[Survey 2: Qual è la massima pena che puo' essere imposta a un CONSUMATORE per non aver rispettato questa legge/regola?]
(1)Un richiamo
(2) multa
(3) Prigione
(4) servizio socialmente utile
(5) libertà vigilata
(6) altri
(7) non lo so

7. Quante persone conosci che sono stati colti o puniti per non aver rispettato questa legge/regola?
(1) Nessuno
(2) 1
(3) $2-10$
(4) 11 o più

8. I tuoi amici rispettano questa legge/regola?
(1) $\mathrm{Si}$
(2) No

9. Tu rispetti questa legge/regola? 


\section{(1) $\mathrm{Si}$ \\ (2) No}

10. Questa legge/regola è esistita in passato?
(1) $\mathrm{Si}$
(2) No

Grazie per la tua partecipazione a questo sondaggio. Le tue risposte sono confidenziali. Se tu fossi interessato a ricevere i risultati generali di questo sondaggio o per qualsiasi domanda riguardo all'argomento scrivi a elena.reznichenko@edle-phd.eu 


\section{Translated to English - Survey 1(and in brackets the changes made in Survey 2): ${ }^{161}$}

This survey asks you questions about your knowledge of a particular law in Italy. There are nine questions and it will take you approximately two minutes to finish. The answers you give in this survey are anonymous and will only be used in aggregate form (that is, individual answers will not be examined, only the trend of answers from all respondents). You will not be identified in any way by the answers you give. Demographic details such as age are gathered only for the purposes of determining aggregate trends in the data, not to identify you. To ensure your answers are completely confidential the IP code (the code which is unique to each computer) will not be collected with the data. Thank you for your help with this research.

If you would like to receive the aggregate results of this survey or have any questions about the subject area please email

1. What is your age and maximum level of education? (e.g. 22, high school)

2. Gender

(1) $\mathrm{F}$

(2) $\mathrm{M}$

3. In which area of Italy did you spend most of your life?
(1) North Italy
(2) South Italy
(3) Outside of Italy

4. According to the current Italian law, are buyers in Italy obliged to take a receipt after making a purchase of any kind?

[Survey 2: According to the current Italian law, are CONSUMERS obliged to ask for a receipt after making a purchase of any kind?]

\section{(1) Yes \\ (2) No}

If you answered 'YES' to the previous question, please continue answering questions 5-9. If you answered 'NO' in the previous question, please answer question 10.

5. How did you come to know about this law/rule?
(1) Family
(2) Friends
(3) News
(4) Schools or University

161 This survey was prepared by the author. 
(5) Other

6. What is the maximum punishment for not complying with this law/rule?

[Survey 2: What is the maximum punishment that can be imposed on a CONSUMER for not complying with this law/rule?]
(1) Warning
(2) Fine
(3) Prison
(4) Community service
(5) Probation
(6) Other
(7) Don’t know

7. How many people do you know who have been caught or punished for not complying with this law/rule?
(1) None
(2) 1
(3) $2-10$
(4) 11 and more

8. Do your friends comply with this law/rule?
(1) Yes
(2) No

9. Do you comply with this law/rule?
(1) Yes
(2) No

10. Did this law/rule exist in the past?
(1) Yes
(2) No

Thank you for your participation in this survey. Your responses are confidential.

If you would like to receive the aggregate results of this survey or have any questions about the subject area please email elena.reznichenko@edle-phd.eu 
